NASA Contractor Report 185113

AIAA-89-2302

\title{
A Premixed Hydrogen/Oxygen Catalytic Igniter
}

James M. Green

Sverdrup Technology, Inc.

NASA Lewis Research Center Group

Cleveland, Ohio

June 1989

Prepared for

Lewis Research Center

Under Contract NAS3-25266

\section{N/Sก \\ National Aeronautics and \\ Space Administration}




\title{
A PREMIXED HYDROGEN/OXYGEN CATALYTIC IGNITER
}

\author{
James M. Green \\ Sverdrup Technology, Inc. \\ NASA Lewis Research Center Group \\ Cleveland, Ohio 44135
}

\begin{abstract}
An experimental program was conducted at the NASA Lewis Research Center to study the catalytic ignition of hydrogen and oxygen propellants using a premixing hydrogen/oxygen injector. The premixed injector was designed to eliminate problems associated with catalytic ignition caused by poor propellant mixing in the catalyst bed. Mixture ratio, mass flow rate, and propellant inlet temperature were varied parametrically in testing, and a pulse mode life test of the igniter was conducted. The results of the tests showed that the premixed injector eliminated flame flashback in the reactor and increased the life of the igniter significantly. The results of the experimental program and a comparison with data collected in a previous program are given.
\end{abstract}

\section{Introduction}

Future reusable rocket engines will require ignition systems that are safe, reliable, lightweight, and low cost to insure mission success. The use of a catalyst to initiate propellant ignition in a reusable hydrogen/oxygen engine is a simple concept that has several potential advantages when compared with other ignition techniques. Catalytic igniters are passive in operation, require no external energy source, and they present no radio interference problems. Catalytic igniters for the decomposition of monopropellant hydrazine have flown in space for periods over eight years, and the use of catalysts for the ignition of hydrogen and oxygen propellants has been studied in the past.

This report presents the results of an experimental program conducted to study the performance of a catalytic igniter utilizing a premixing hydrogen/ oxygen injector.
The concept of using catalysts to ignite the hydrogen/oxygen propellant combination was studied in the 1960's and early 1970's, 1,2 and an experimental data base was created. This early research identified flashback, which is the propagation of the flame from the catalyst bed back to the injector face, as one of the key problems associated with catalytic ignition. Flashback often resulted in the destruction of the catalyst and reactor hardware, and different approaches were attempted in an effort to characterize, if not alleviate, the problem. Localized propellant streaks and mixture ratio transients were identified as one source of flashback, caused by poorly mixed propellants entering the catalyst bed. Mixing zones and inert diffusion beds were both incorporated in an attempt to arrest flashback by allowing the propellants to mix thoroughly before entering the catalyst bed.

Additional research, which preceded this study, also showed that the injector was the critical component in the design of an effective catalytic igniter. This study also showed that if the propellants were not well mixed when they enter the catalyst bed, localized hot spots in the bed and flashback could occur. ${ }^{3}$ Since mixing zones or diffusion beds had not been shown to eliminate flashback in catalytic igniters, an injector was needed that would introduce a uniform hydrogen/oxygen mixture into the catalyst bed.

The goals of the present experimental program were to enhance and characterize the performance of a gaseous hydrogen/oxygen catalytic igniter which employed a premixed injector design and to add to the experimental data base for hydrogen/oxygen catalytic ignition. This report details the hardware, facility, and test procedures used for this experiment. The results of testing at 
variable mass flow rates, mixture ratios, and propellant inlet temperatures are given, and the results of life testing of the igniter are also presented.

\section{Apparatus}

\section{Test Hardware}

The hardware used for this experiment was similar to that used in Ref. 3. It consisted of an upstream injector, spool piece, downstream injector, and nozzle. A schematic of the hardware is shown in Fig. 1. The principle hardware modification for this program was the design and fabrication of an injector that mixed the upstream hydrogen and oxygen before injection into the catalyst bed. The design chosen for this program was a platelet design. Fig. 2 shows a photograph of the platelet injector, which consisted of sixty $0.356 \mathrm{~mm}(0.014 \mathrm{in}$.) diameter orifices in the $12.70 \mathrm{~mm}$ (0.50 in.) diameter face plate, and Fig. 3 shows a schematic of one of the platelet injector elements, Before exiting through each of the outer orifices, two fuel streams exited through two $0.1702 \mathrm{~mm}(0.0067 \mathrm{in}$.) diameter orifices and one oxidizer stream exited through one $0.1194 \mathrm{~mm}$ (0.0047 in.) diameter orifice, and the three streams mixed. For comparison, the upstream injector used in Ref. 3 was a showerhead type injector in which the hydrogen and oxygen flowed axially into the reactor and a diffusion bed of inert material was used to achieve propellant mixing.

After exiting the upstream injector, the hydrogen/oxygen mixture entered the catalyst bed, or reactor, which was contained in the spool piece. Shell 405 catalyst was used to ignite the propellants in this program, and the catalyst specifications are given in Table 1 . Since no diffusion bed was necessary to help mix the propellants, the catalyst bed filled the $50.80 \mathrm{~mm}$ (2.00 in) long by $12.70 \mathrm{~mm}$ (0.50 in) diameter reactor. The spool piece contained six Type $\mathrm{K}$ (chromel constantan) thermocouples inside the catalyst bed at the locations shown in Fig. 1. These thermocouples, labeled T1 through T6, were placed just inside the reactor in the catalyst bed. Four back wall thermocouples were also used for diagnostic purposes, and one pressure measurement was taken inside the catalyst bed using a strain gauge type pressure transducer, at the location shown in Fig. 1.

After ignition in the catalyst bed, the combustion gases passed through the downstream injector into the downstream combustion chamber and nozzle. The downstream injector was designed to add secondary oxygen to the combustion gases from the catalyst bed. The total mixture ratio could then be raised to values at or above stoichiometric to provide maximum energy for main propellant ignition, while operating at low mixture ratios in the catalyst bed to prolong the life of the reactor.

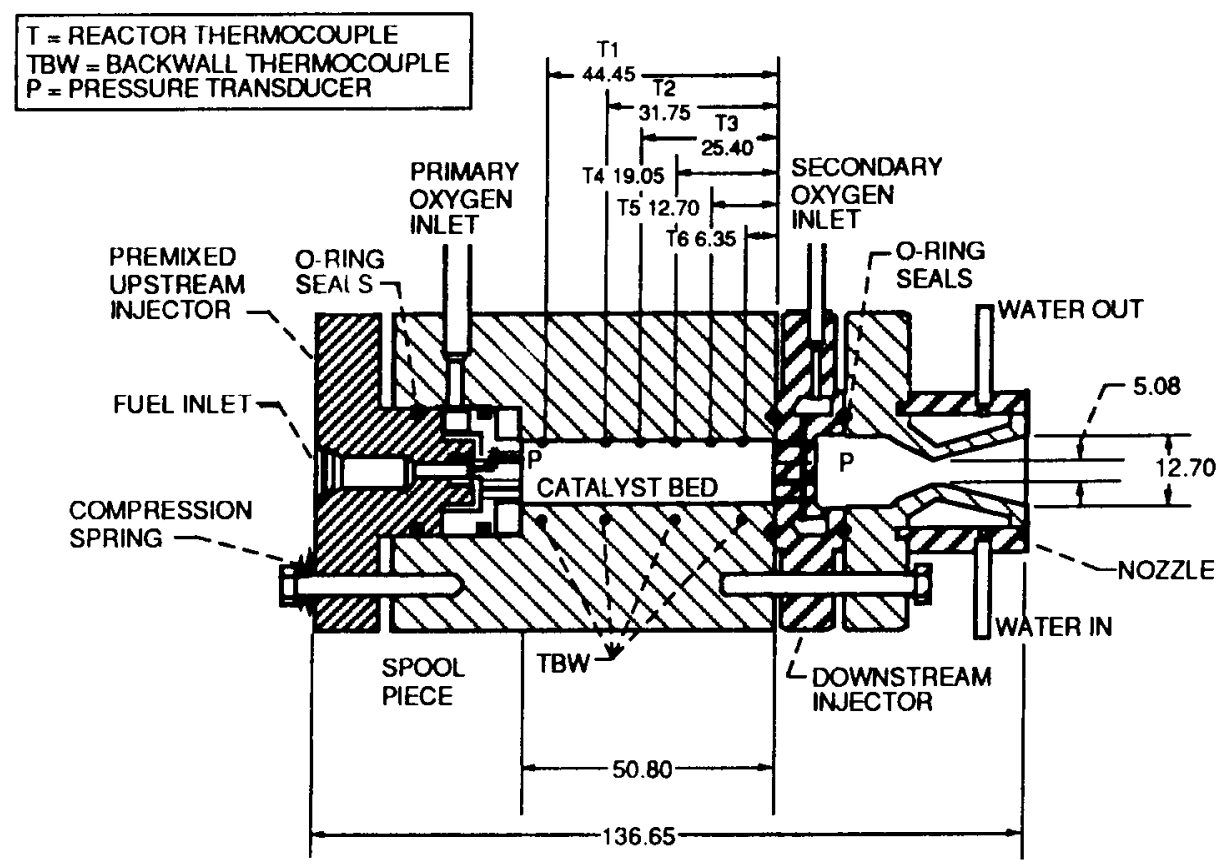

Figure 1. - Schematic of catalytic ignitor. 


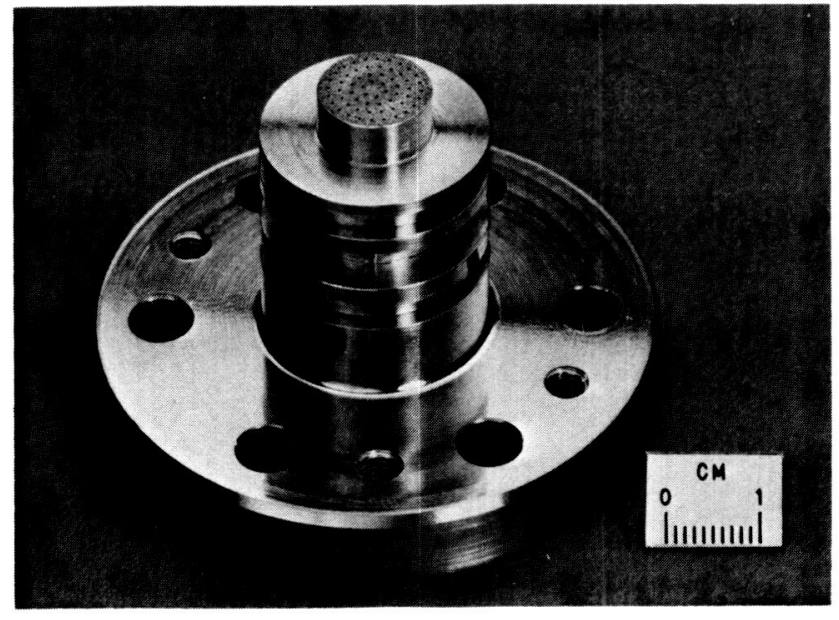

Figure 2. - Photograph of premixed injector.

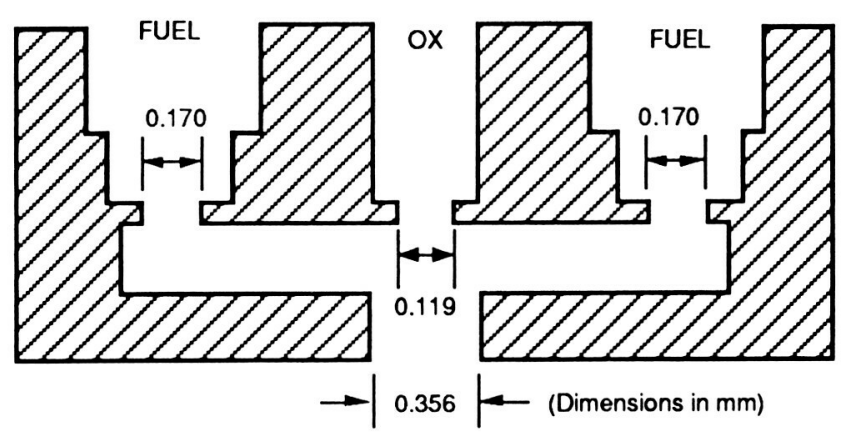

Figure 3. - Schematic of platelet injector element.

The downstream injector consisted of a cross-drilled design in which the combustion gases passed axially through twelve $1.02 \mathrm{~mm}$ (0.040 in) diameter orifices into the downstream chamber, and the secondary oxygen entered from the annulus through nine $0.640 \mathrm{~mm}(0.025 \mathrm{in})$ diameter orifices. The nozzle was water cooled and had a throat diameter of $5.080 \mathrm{~mm}(0.200 \mathrm{in})$ and an exit diameter of $12.70 \mathrm{~mm}$ (0.50 in), yielding a value of 6.25 for both the expansion and contraction ratios of the nozzle. One strain gauge type pressure transducer was installed in the downstream chamber as shown in Fig. 1.

\section{Test Facility}

Testing of the catalytic igniter took place in the Combustion Research Laboratories at NASA Lewis. The test facility, which was designed and built for the testing of ignition systems and small gaseous hydrogen/oxygen rockets (up to $50 \mathrm{lbf}$ thrust), was capable of testing at sea level or space simulated altitude, with ambient or chilled propellants. Fig. 4 shows a photograph of the

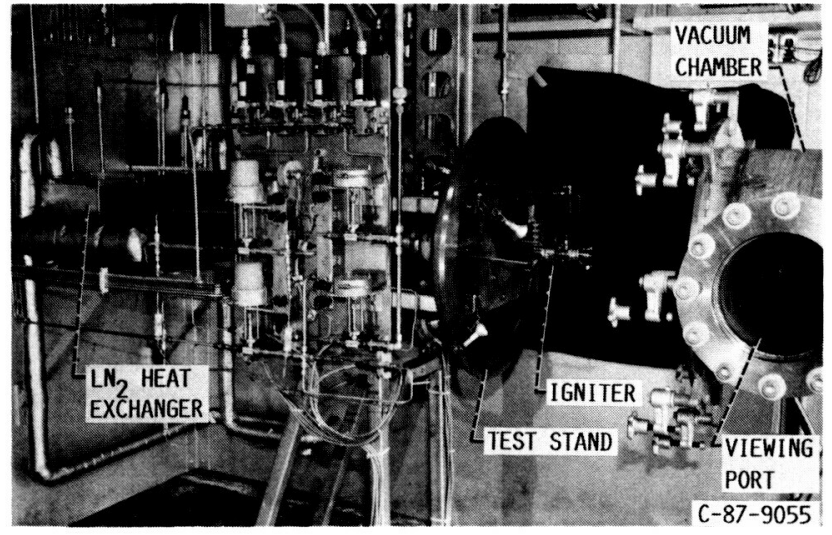

Figure 4. - Test stand.

test stand. A summary of the facility capabilities will be presented here, with a more detailed description available in Ref. 3.

The feed system for the facility consisted of two gaseous oxygen feed lines and one gaseous hydrogen feed line. Sonic orifices were used to control the mass flow rate in all the propellant lines, and a gaseous nitrogen system was used to purge all the propellant lines. The inlet temperature of each propellant was controlled by passing the propellant through a boiling liquid nitrogen heat exchanger. A programmable control system was used to open and close valves during the run based on manually entered timing values, and manual and automatic aborts were set in case a problem occurred during testing. The test cell had both high speed and low speed data acquisition systems, and a high speed data program on a mainframe computer performed calculations with the raw high speed data. A minicomputer and a strip chart recorder were used to monitor the facility and obtain local, immediate data acquisition during testing, and each test was monitored and recorded on video tape.

\section{Test Procedure}

Pulse mode testing, which simulated the repeated use of an igniter with a reusable engine, was used for this program. Each hot fire pulse was either 2 or $3 \mathrm{sec}$ in duration, preceded by a hydrogen lead flow to insure smooth startup and followed by a hydrogen lag flow to insure smooth shut down. The catalyst bed was then purged with nitrogen gas to remove all of the residual propellants. Pulse life testing consisted of a series of 2-sec pulses followed by a 13-sec cool down period between firings. New catalyst beds were conditioned by flowing hydrogen through the bed for approximately $1 \mathrm{~min}$ prior to the test. This 
hydrogen purge activated the catalyst bed by removing residual oxygen adsorbed on the surface during the handling of the catalyst.

Tests were conducted over a wide range of operating conditions to define the characteristics of the igniter. The mixture ratio in the catalyst bed was varied from 0.30 to 1.23 , with a nominal operating value of 1.0. The mass flow rate through the catalyst bed was varied from $0.0005 \mathrm{~kg} / \mathrm{sec}(0.0010 \mathrm{lbm} / \mathrm{sec})$ to $0.0028 \mathrm{~kg} / \mathrm{sec}$ $(0.0062 \mathrm{lbm} / \mathrm{sec})$, with a nominal operating value of $0.0018 \mathrm{~kg} / \mathrm{sec}(0.0040 \mathrm{lbm} / \mathrm{sec})$. Propellant inlet temperature was varied from ambient to $-143.6^{\circ} \mathrm{C}\left(-226.4^{\circ} \mathrm{F}\right)$. The performance of the igniter with downstream oxygen ignition was not characterized for this study, and all of the testing was conducted at ambient pressure.

\section{Results and Discussion}

The mixture ratio in the catalyst bed was varied to determine its effect on the temperature distribution in the reactor. This mixture ratio was defined by the relation:

$$
\mathrm{O} / \mathrm{F}=\frac{\dot{\mathrm{m}}_{\mathrm{O}_{2}}}{\dot{\mathrm{m}}_{\mathrm{H}_{2}}}
$$

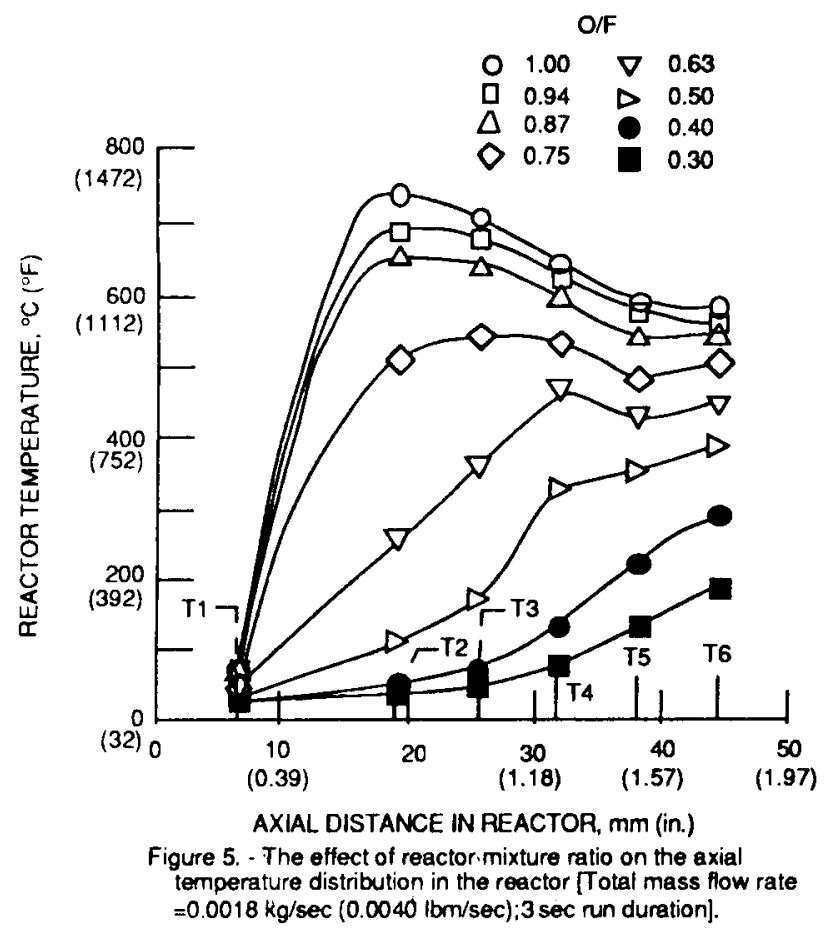

where

$\mathrm{O} / \mathrm{F} \quad$ the reactor, or catalyst bed, mixture ratio

$\begin{array}{ll}\dot{\mathrm{m}}_{\mathrm{O}_{2}} & \text { the oxygen mass flow rate in } \\ \mathrm{kg} / \mathrm{sec}(\mathrm{lbm} / \mathrm{sec})\end{array}$

$\dot{\mathrm{m}}_{\mathrm{H}_{2}} \quad \begin{aligned} & \text { the hydrogen mass flow rate in } \\ & \mathrm{kg} / \mathrm{sec}(\mathrm{lbm} / \mathrm{sec})\end{aligned}$

Fig. 5 shows the effect of mixture ratio on the axial temperature distribution in the reactor at the end of a three second firing at a total mass flow rate of $0.0018 \mathrm{~kg} / \mathrm{sec}(0.0040 \mathrm{lbm} / \mathrm{sec})$. This graph shows that not only did the temperature at each measurement point increase with increasing $\mathrm{O} / \mathrm{F}$, but the flame front, indicated by the point of maximum temperature, moved upstream in the reactor. In the previous work, 3 the flame front remained at or near the end of the reactor or changed unpredictably due to poor mixing of the propellants causing localized hot spots. With the premixed injector, however, the propellants were well mixed and the flame front location was dependent on the ignitability of the mixture (the $\mathrm{O} / \mathrm{F}$ ). Thus, as the mixture became easier to ignite (as the $\mathrm{O} / \mathrm{F}$ increased), less catalyst surface area was required to promote the ignition, and the flame front moved upstream in the reactor.

The two main causes of flame flashback have been identified as localized regions of high mixture ratio or propellant streaking and low flow velocity, or mass flow rate, in the catalyst bed. 2 The premixed injector was designed to eliminate the

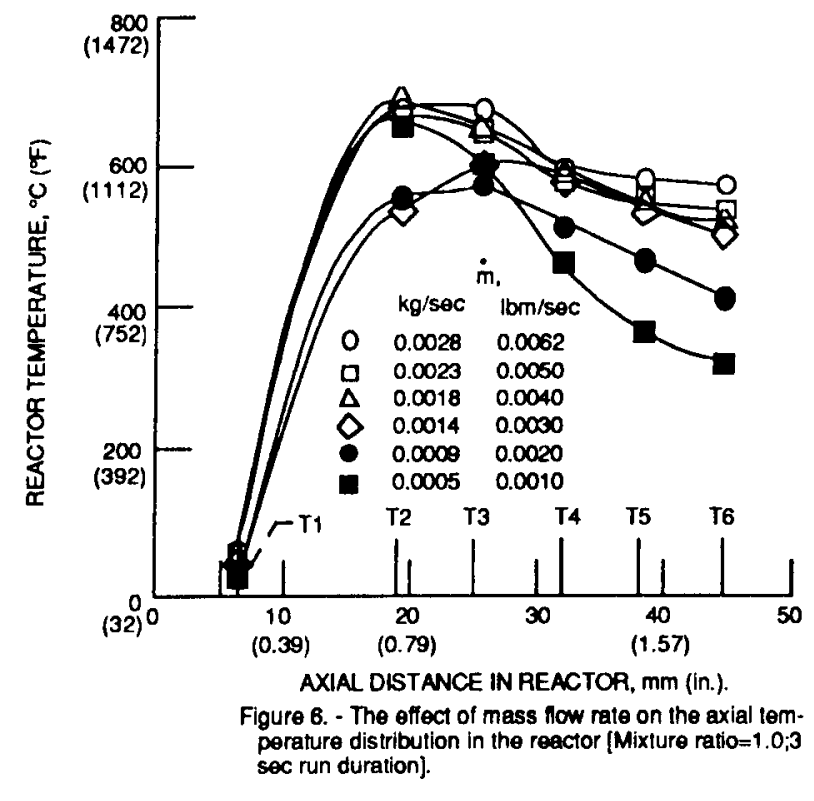


former cause of flashback by improving the mixing of the propellants. To determine the effect of mass flow rate (which is directly related to velocity) on the axial temperature distribution in the bed, and to characterize the flashback phenomena, tests were conducted in which the total mass flow rate in the reactor was varied from a value of $0.0028 \mathrm{~kg} / \mathrm{sec}(0.0062 \mathrm{lbm} / \mathrm{sec})$ to $0.0005 \mathrm{~kg} / \mathrm{sec}(0.0010 \mathrm{lbm} / \mathrm{sec})$, which was the minimum flow rate the feed system was capable of delivering accurately. Fig. 6 shows the results of these tests, which consisted of a 3-sec firing at a catalyst bed mixture ratio of 1.0. In each of these runs the flame front was located 19.05 to $25.40 \mathrm{~mm}$ ( 0.75 to 1.00 in.) from the injector face. The effect of propellant velocity can be seen by looking at the temperature distribution in the last half of the catalyst bed. Since the ignition had already taken place in the first half of the reactor, the gases were simply losing heat as they continued through the reactor. This heat loss was due to conduction to the outer walls and the warming up of the catalyst substrate. The combustion gases in the runs with lower velocity (lower mass flow rate) cooled more extensively in the final stages of the reactor due to their longer residence time.

Not a single flashback occurred throughout the variable mass flow rate testing or the entire test program. This elimination of flashback was a significant result that can be attributed to the premixed injector, which eliminated the localized regions of high temperature and oxidizer streaks that were prevalent in the showerhead injector testing. ${ }^{3}$ Even under conditions of low flow velocity (low mass flow rate), flashback was eliminated for this reactor design.

Since many potential applications for the catalytic igniter may require the use of low temperature propellants, testing was conducted to determine the ignition limits of the igniter with chilled propellants. Fig. 7 shows the results of these tests, in which the mixture ratio and propellant inlet temperature were varied while the mass flow rate was held constant at $0.0018 \mathrm{~kg} / \mathrm{sec}$ $(0.0040 \mathrm{lbm} / \mathrm{sec})$ and the run duration was three seconds. Both the ignition boundary defined using the premixed injector and the boundary found in the previous work using the showerhead injector ${ }^{3}$ are shown in the figure. Although the curves are similar, it should be noted that the inlet temperature for each of these cases was determined differently due to the different designs of the injectors. Because of flow control problems that occurred when the heat exchanger liquified the oxygen, ambient temperature oxygen had to be used for these tests. With the showerhead injector, the oxygen was injected directly into the igniter before mixing with the hydrogen that was chilled to approximately -130 to $-190^{\circ} \mathrm{C}(-200$ to $-300^{\circ} \mathrm{F}$ ). To simulate chilled ignition, the reactor was prechilled by flowing cold hydrogen until the catalyst bed attained the desired temperature, and the temperature used in Fig. 7 was the catalyst bed initial temperature. With the premixed injector, however, the cold hydrogen and the ambient oxygen mixed before entering the catalyst bed, and the actual average propellant inlet temperature was used in Fig. 7. The inlet temperature of the propellant mixture was calculated using a weighted average of the form:

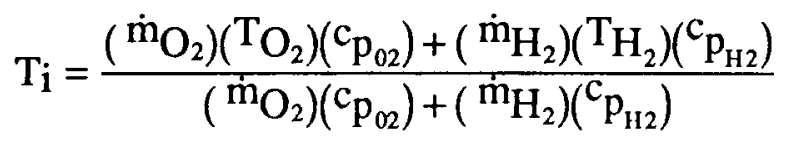

where

$\mathrm{T}_{\mathrm{i}} \quad$ propellant inlet temperature in $\mathrm{K}$ $\left({ }^{\circ} \mathrm{R}\right)$

$\begin{array}{ll}\stackrel{\dot{\mathrm{m}}}{\mathrm{O}_{2}} & \begin{array}{l}\text { oxygen mass flow rate in } \mathrm{kg} / \mathrm{sec} \\ (\mathrm{lbm} / \mathrm{sec})\end{array} \\ \mathrm{T}_{\mathrm{O}_{2}} & \text { oxygen inlet temperature in } \mathrm{K}\left({ }^{\mathrm{O}} \mathrm{R}\right) \\ \mathrm{c}_{\mathrm{p}_{02}} & \begin{array}{l}\text { oxygen specific heat in } \mathrm{kJ} / \mathrm{kg} \cdot \mathrm{K} \\ \left(\mathrm{BTU} / \mathrm{lbm}^{\circ} \mathrm{R}\right)\end{array}\end{array}$

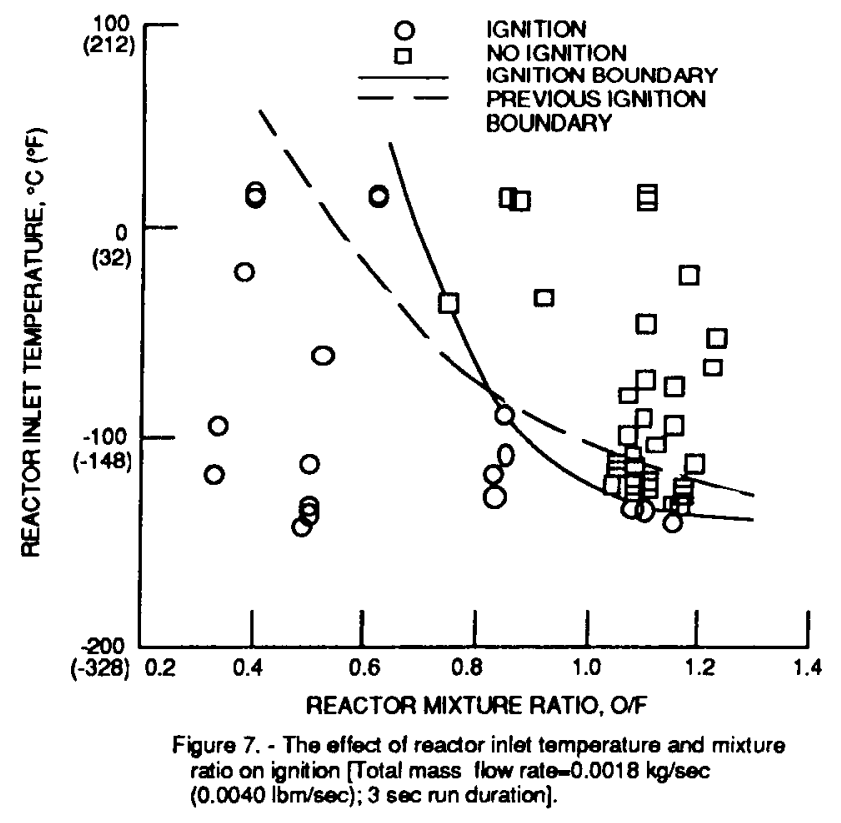




$\begin{array}{ll}\dot{\mathrm{m}}_{\mathrm{H}_{2}} & \begin{array}{l}\text { hydrogen mass flow rate in } \mathrm{kg} / \mathrm{sec} \\ \text { (lbm/sec) }\end{array} \\ \mathrm{T}_{\mathrm{H}_{2}} & \begin{array}{l}\text { hydrogen inlet temperature in } \mathrm{K} \\ \left({ }^{\circ} \mathrm{R}\right)\end{array} \\ \mathrm{c}_{\mathrm{p}_{\mathrm{H} 2}} & \begin{array}{l}\text { hydrogen specific heat in } \mathrm{kJ} / \mathrm{kg} \cdot \mathrm{K} \\ \left(\mathrm{BTU} / \mathrm{lbm} \cdot{ }^{\circ} \mathrm{R}\right)\end{array}\end{array}$

The specific heats of the gases were assumed to be constant and were calculated using the arithmetic average of the propellant inlet temperatures. The catalyst bed was not prechilled with hydrogen before the run.

Despite the differences in inlet temperature calculation, the low temperature ignition boundaries can be compared qualitatively by referring to Fig. 7. At lower mixture ratios, the showerhead injector provided easier ignition. This was caused by localized regions of higher mixture ratio igniting and then igniting the rest of the flow. The disadvantage of this apparent benefit of poor mixing is that starting is more difficult and the chance of flashback is increased. The well mixed propellants from the premixed injector simply did not ignite at the lower mixture ratios when the propellant inlet temperature was reduced. The premixed injector did promote ignition at a slightly lower temperature than the showerhead injector. The lowest ignitable inlet temperature for the premixed injector was $-133.5{ }^{\circ} \mathrm{C}\left(-208.3^{\circ} \mathrm{F}\right)$, compared to $-112.8{ }^{\circ} \mathrm{C}\left(-171.0{ }^{\circ} \mathrm{F}\right)$ for the showerhead injector. The differences in the ignition boundaries for the two configurations is small, and qualitatively the injectors can be considered equivalent in terms of low temperature ignition.

One of the most demanding requirements of a catalytic igniter is that it must operate reliably for a long lifetime. To determine the life of the catalytic igniter with the premixed injector, a series of pulse mode tests were conducted. The tests consisted of a $2-\mathrm{sec}$ hot fire at a mixture ratio of 1.0 and a total mass flow rate of $0.0018(0.004 \mathrm{lbm} / \mathrm{sec})$ followed by a 13-sec cool down period between firings. A total of over 4900 hot fire pulses were attained with the igniter without damage. The igniter was still operational at this point since no drop in maximum reactor temperature was observed, indicating that the igniter could have operated for many more pulses. The temperature distribution in the reactor did change as the number of pulses increased, however, and this

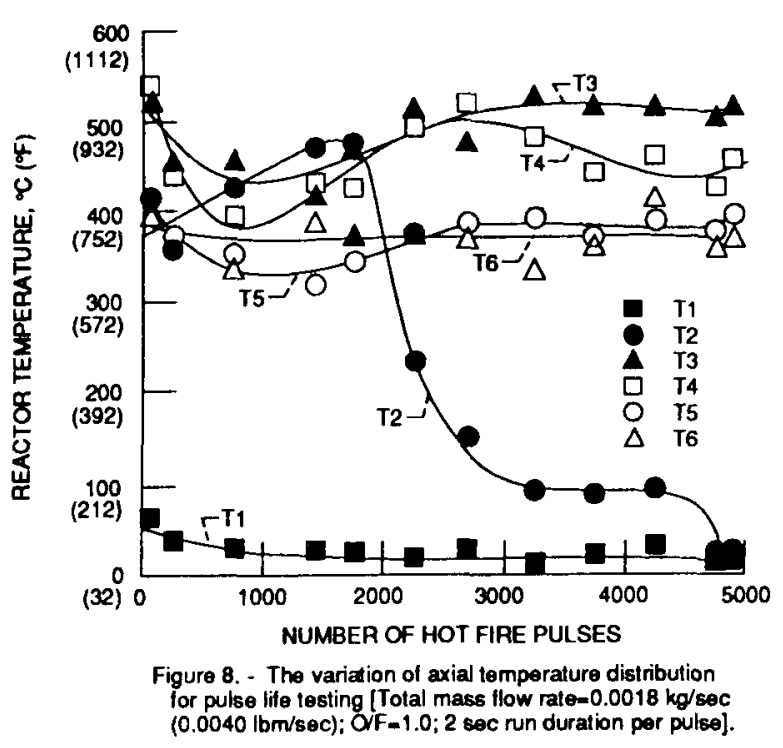

effect is shown in Fig. 8. For approximately the first 750 pulses, the flame front was located approximately $25.40 \mathrm{~mm}$ (1.00 in.) from the injector face. Then, as the number of pulses increased from 1000 to 2000 , the flame front actually moved upstream slightly and $\mathrm{T} 2$ became the hot spot in the reactor. As the life test progressed, however, $\mathrm{T} 2$ rapidly decreased after approximately 2000 pulses, and the flame front remained at T3 for the remaining pulses. Although the location of the flame front changed with increasing pulse number, the temperature at the final thermocouple, T6, remained steady at approximately $375^{\circ} \mathrm{C}\left(707^{\circ} \mathrm{F}\right)$ throughout the testing. This was an indication of the consistency of operation of the igniter. Upon inspection of the igniter after the pulse life tests, a loss of catalyst

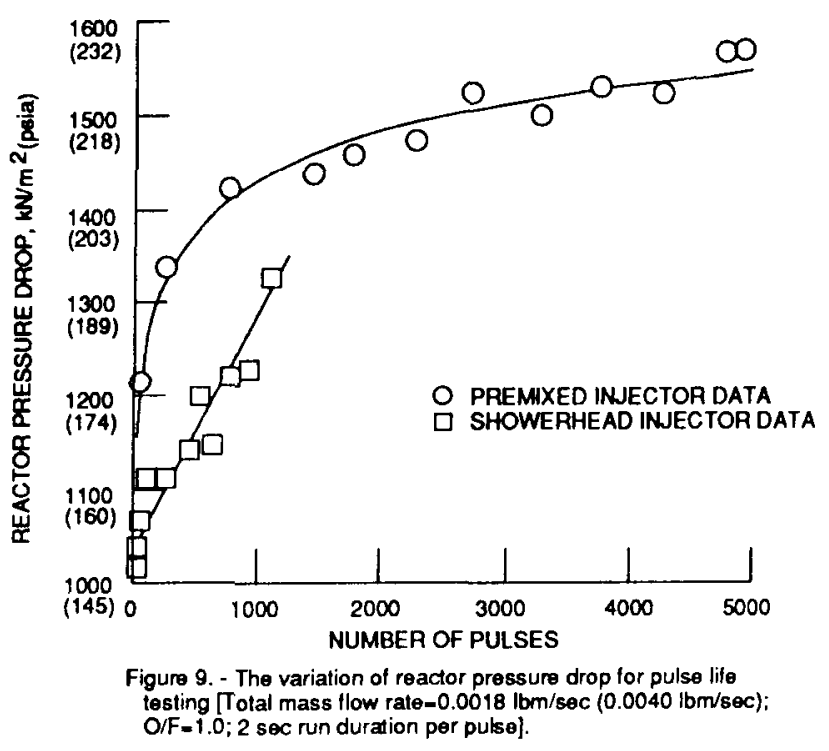


and a discoloration and breakup of some of the catalyst was observed. Despite this degradation, the maximum reactor temperature and the exit temperature of the igniter remained consistent. The igniter used in Ref. 3 had a life of nearly 2000 hot fire pulses. The premixed injector therefore offered a significant increase in the igniter life.

The pressure drop across the catalyst bed and downstream injector for the pulse life tests are shown in Fig. 9 for both the premixed and showerhead configurations. A direct comparison between the two curves cannot be made since the premixed configuration did not employ a diffusion bed and the catalyst bed was $12.70 \mathrm{~mm}(0.50 \mathrm{in}$.) longer than in the showerhead configuration, but again a qualitative analysis of the trends can be made. The diffusion bed in the previous study consisted of $2.38 \mathrm{~mm}$ (0.094 in.) diameter stainless steel balls. Since these balls were larger than the catalyst material, there was a lower pressure drop across the diffusion bed than in an equal amount of catalyst. For this reason, the initial pressure drop in the reactor was lower than the reactor without a diffusion bed. As testing progressed, however, the stainless steel diffusion bed deteriorated and sintered together, causing a rise in pressure drop that was nearly linear with pulse number. In the premixed reactor the pressure drop was slightly higher, but remained relatively constant throughout the test, increasing only gradually with pulse number. Thus, the elimination of the diffusion bed enabled the igniter to operate in a much more stable manner in terms of reactor pressure drop.

\section{Conclusion}

An experimental program was conducted at NASA Lewis to study the catalytic ignition of gaseous hydrogen and oxygen propellants using a premixing injector for propellant injection into the catalyst bed. The goals of the experimental program were to enhance and characterize the performance of a hydrogen/oxygen catalytic igniter by employing a premixed injector design and to add to the experimental data base for hydrogen/oxygen catalytic ignition.

The premixed injector was designed to introduce well mixed propellants into the catalyst bed, and thereby lead to more consistent operation and a longer life. The results of this program proved this concept. The significant results of the program can be summarized as follows:

- Localized hot spots and oxidizer rich streaks in the catalyst bed were eliminated due to the efficient mixing of the premixed injector, and a diffusion bed or mixing zone was not required.
- Flame flashback was eliminated for all operating conditions.

- Ignition was achieved at average propellant inlet temperatures as low as $-133.5^{\circ} \mathrm{C}(-208.3$

$\left.{ }^{\circ} \mathrm{F}\right)$, and a low temperature ignition boundary was defined.

- A life test consisting of over 49002 -sec hot fire pulses was completed with the igniter still fully operational.

The concept of catalytic ignition of hydrogen and oxygen propellants is a proven, reliable concept, and the operational characteristics of catalytic igniters are well defined in this and previous reports. ${ }^{1-3}$ The addition of the premixed injector used in this study offers a significant improvement in igniter design by eliminating flame flashback, which had been a major downfall of catalytic ignition in the past, and by significantly increasing the life of the igniter.

\section{Acknowledgement}

This work was sponsored by NASA Lewis under contract NAS3-25266 with Mr. Carl A. Aukerman as monitor. Special acknowledgement goes to Mr. Robert L. Zurawski, Mr. John F. Schubert, and Mr. Richard A. Gardin.

\section{References}

1. Roberts, R.W., Burge, H.L., and Ladacki, M., "Investigation of Catalytic Ignition of Oxygen/Hydrogen Systems", R-6303, Rockwell International Corporation, Canoga Park, CA, December 1965, NASA CR-54657.

2. Johnson, R.J., "Hydrogen-Oxygen Catalytic Ignition and Thruster Investigation; Volume I - Catalytic Ignition and Low Pressure Thruster Evaluations", TRW-14549-6001-RO-00-VOL-1, TRW Systems Group, Redondo Beach, CA, November 1972, NASA CR-120869.

3. Zurawski, R.L. and Green, J.M., "Catalytic Ignition of Hydrogen and Oxygen Propellants", AIAA Paper-88-3300, July 1988, NASA TM 100957 
TABLE I. - SHELL 405 CATALYST SPECIFICATIONS

\begin{tabular}{|c|c|c|}
\hline \multicolumn{3}{|c|}{ Catalyst carrier } \\
\hline Size and shape & \multirow{5}{*}{\multicolumn{2}{|c|}{$\begin{array}{l}14 \text { to } 18 \text { mesh rounded granules } \\
\text { Alumina, type RA-1 } \\
211 \mathrm{~m}^{2} / \mathrm{g}\left(1.03 \times 10^{6} \mathrm{ft}^{2} / \mathrm{bm}\right) \\
0.999 \mathrm{~g} / \mathrm{cm}^{3}\left(0.036 \mathrm{lbm} / \mathrm{in} .^{3}\right) \\
0.23 \mathrm{~cm}^{3} / \mathrm{g}\left(6.37 \mathrm{in} .^{3} / \mathrm{lbm}\right)\end{array}$}} \\
\hline Carrier type & & \\
\hline Surface area & & \\
\hline Bulk density & & \\
\hline Pore volume & & \\
\hline \multicolumn{3}{|c|}{ Finished catalyst } \\
\hline Active catalyst & & Iridium \\
\hline Active material & & $32.2 \mathrm{wt} \%$ \\
\hline Total surface are & & $\begin{array}{c}124 \mathrm{~m}^{2} / \mathrm{g} \\
\left(6.05 \times 10^{5} \mathrm{ft}^{2} / \mathrm{lbm}\right)\end{array}$ \\
\hline Active surface ar & & $\begin{array}{l}417 \mu \mathrm{mol} \mathrm{H} \\
\text { Adsorbed } / \mathrm{g}\end{array}$ \\
\hline
\end{tabular}




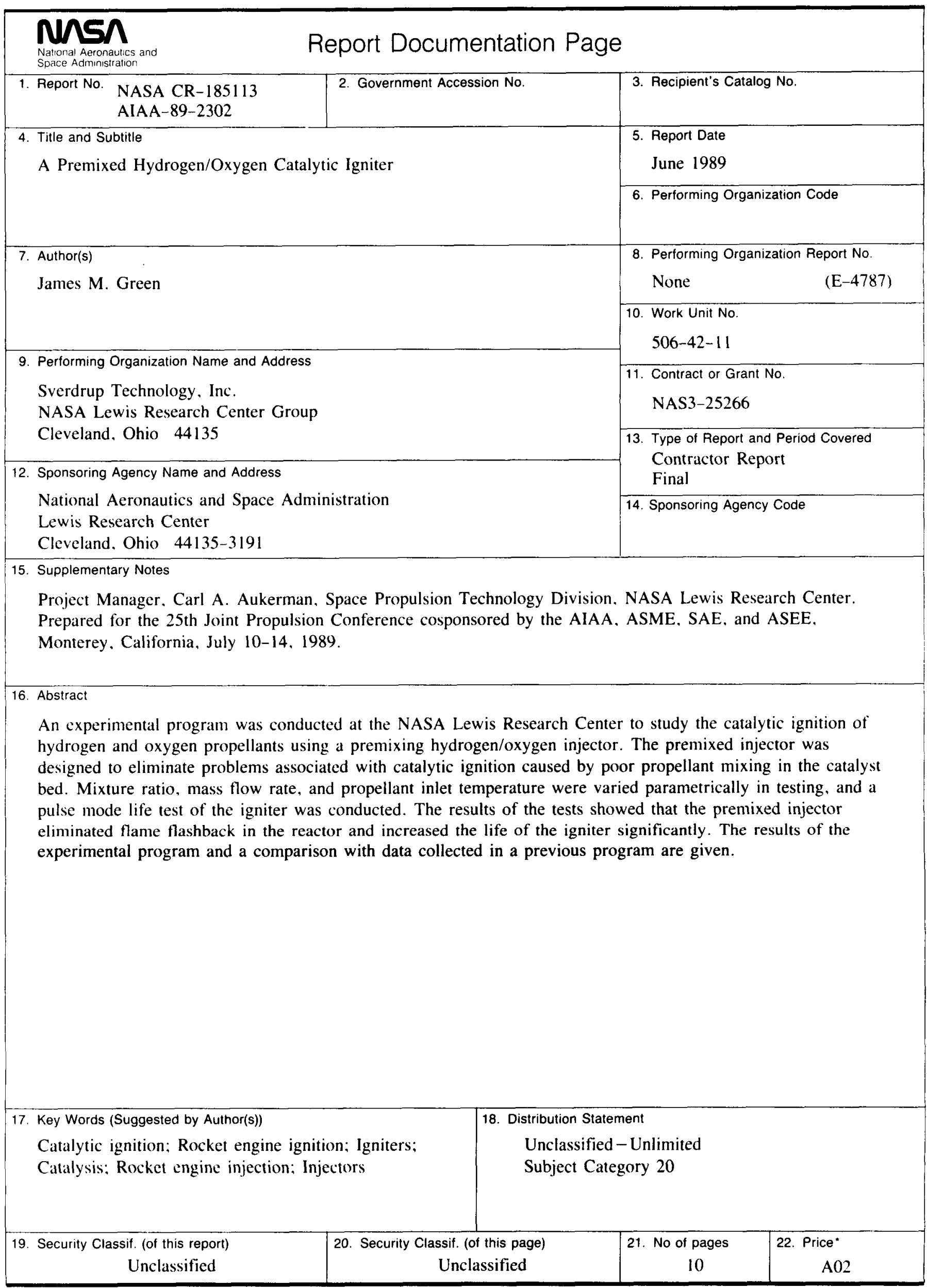

